\title{
Has Local Government Debt Promoted Economic Growth in developing countries? New evidence from a survey in China
}

\author{
Tao $\mathrm{Wu}^{1}$, Peng Zhong ${ }^{2}, *$, Lingyue $\mathrm{Wu}^{3}$ \\ ${ }^{1}$ School of Finance, Chongqing Technology and Business University, Chongqing, 400067, China. \\ ${ }^{2}$ School of Economics, Sichuan University, Chengdu city, Sichuan,610065, China. \\ ${ }^{3}$ Chongqing Foreign Language School, Chongqing, 400039, China.
}

\begin{abstract}
Based on the panel smooth transition regression (PSTR) model, this paper empirically analyzes the relationship between Chinese local government's bond financing and economic growth, with the quarterly panel data of bonds issued by local governments and their investment and financing platform companies in the open market from 2008 to 2018 as samples. The research shows that there is a gradual non-linear relationship between local government bond market financing and economic growth in China. With the increase of the scale of local government bond market financing in China, the effect of bond market financing on economic growth will gradually decline and have a negative effect. This result means that for developing countries like China, it is not advisable to rely solely on government investment to drive economic growth.
\end{abstract}

\section{Introduction}

In the midst of the 2008 global financial crisis, the Chinese Government implemented a RMB 4 trillion economic stimulus plan. In the implementation process, local governments at all levels in China set up local government investment and financing platform companies (hereinafter referred to as "platform company") to carry out the investment projects, while raising money through different channels to support the implementation. Consequently, local governments have built up huge government debts, which are divided into "explicit debts" and "implicit debts", with the latter characterized by difficulty to count and data distortion. Therefore, "making implicit debts explicit" has become the key to debt risk management for local governments.

So far, a large number of foreign studies have examined how government debts impact economic growth, but the findings vary greatly. Some foreign scholars argue that governments' debt-financed investment can promote economic growth, including Tiebout [1], Hildreh \& Miller [2], Panizza \& Presbitero [3], Stella \& George [4], etc. However, some scholars have reached completely different conclusions: for example, Dotsey argued that governments' debt-financed investment will lead to future tax distortions and hinder economic growth [5]; Baldaccie \& Kumar and Cochrane argued that high government debt will hinder economic growth by changing people's expectations of long-term inflation [6-7]. Such disagreement has led scholars to explore the non-linear effects of government debt. Reinhart \& Rogoff found that government debt has a threshold effect on economic growth [8]. Checherita \& Rother and Mitze \& Matz found an inverted U-shaped relationship between government debt and economic growth in eurozone countries [9-10].

In recent years, researchers in China have also examined the above topics extensively. In general, their findings can be summarized into the following three conclusions: (1) local government's debt financing is not conducive to economic growth (Diao Weitao [11]; Xiang Houjun [12]); (2) local government's debt financing helps to promote economic growth (Fan Jianyong [13]; Xu Changsheng [14]); (3) local government's debt financing has threshold effect on economic growth (Zhu Wenwei [15]; Mao Jie [16]). Such disagreements are mainly attributed to inconsistent sources of data on local government debts used in different studies. What's more, some researchers have come to different conclusions on the basis of approximate data.

The classical growth theory (Keynes, 1936) always argues that the government can stimulate economic growth via investment. In general, why governments' debt-financed investment can stimulate economic growth can be described as follows (as shown in Figure 1): Firstly, the local government will invest a large amount of borrowed funds in public infrastructure ("public investment") in order to improve local conditions for attracting more firms to set up operations ("private investment"), thus resulting in more tax revenue and local growth. Secondly, following the government's debtfinanced investment, more firms will emerge, creating more jobs and increasing residents' income and demand, which eventually leads to local economic growth. Thirdly, local government's debt-financed investment will generally produce strong external linkage effects. For example, after investing borrowed funds in public infrastructure projects, governments will generally require

*Corresponding author’s e-mail: zp3gu@vip.163.com 
building materials to be procured locally, thus propelling the development of local industries, such as construction and cement, which will in turn drive the development of related downstream industries. Therefore, it is generally believed that local government's debt-financed investment has a positive effect on economic growth. Accordingly, we put forward Hypothesis 1.

$\boldsymbol{H}_{1}$ : all other factors remaining unchanged, Chinese local government's bond financing can promote economic growth.

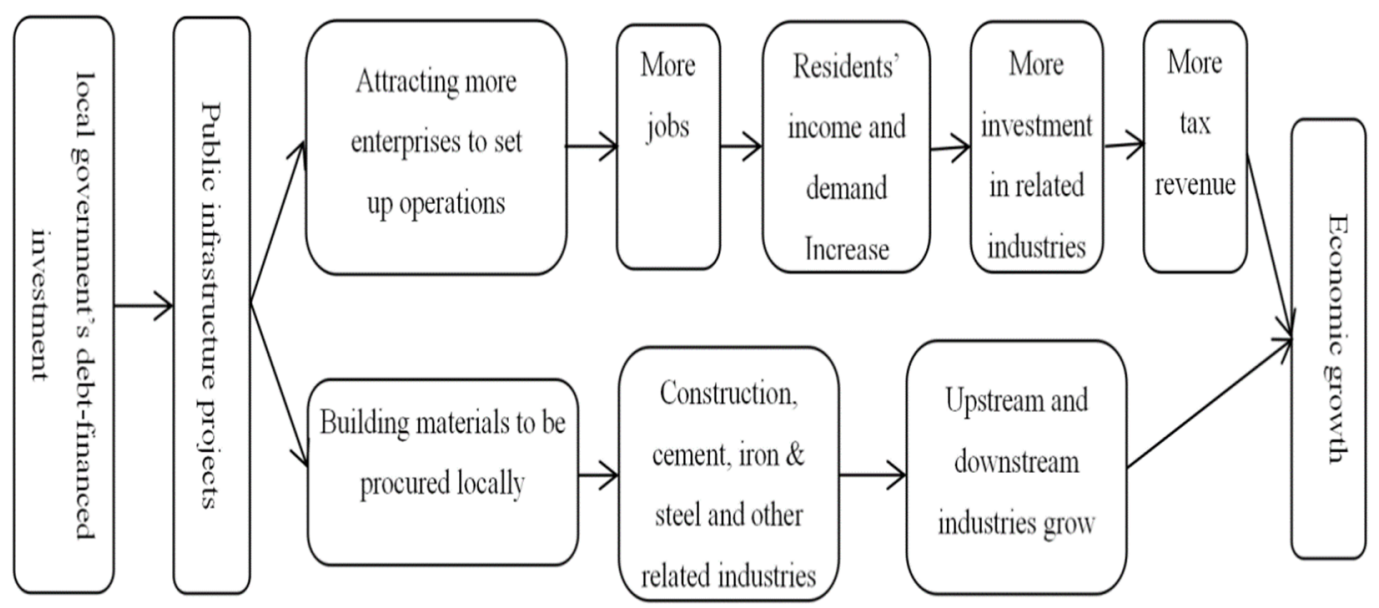

Fig1. Flowchart of how local government's debt-financed investment boosts economic growth.

The theory of production function in neoclassical economics holds that the marginal product of any factor of production will eventually decline. Accordingly, it can be inferred that when the government's financing and investment reaches a certain level, the growth rate will decrease correspondingly. China's economic stimulus practice seems to support this view. The annual growth rate of China's economy rose from $8.5 \%$ (2000) to $14.2 \%$
(2007), but fell to $9.7 \%$ (2008) after it was hit by the 2008 financial crisis. In order to reverse the downward trend in the economy, Chinese government implemented a RMB4 trillion stimulus plan in 2008. Subsequently, the downward trend was contained in 2009. The growth rate rose to $10.6 \%$ in 2010 , but then entered a period of yearon-year slowdown (Figure 2).

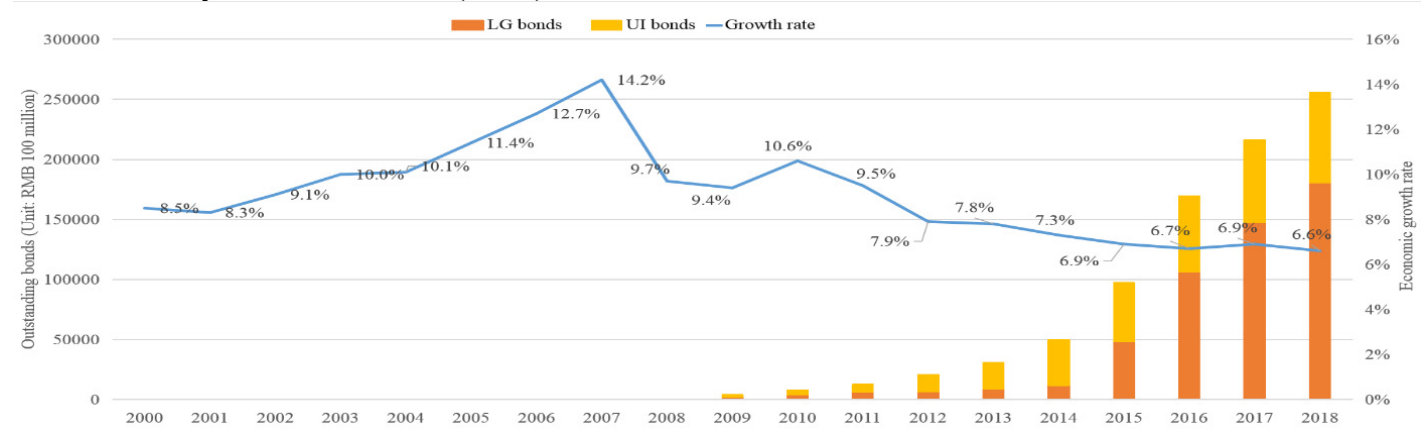

Fig2. Annual GDP growth rate of China, 2000 to 2018 .

Some previous studies as well as practical experience suggest that the decline of growth rate following local government's debt-financed investment is attributed to many factors: First of all, due to the lack of hard budget constraints and shortage of specialists, local governments tend to invest borrowed funds in public facilities and prestige projects that produce little or no return $(\mathrm{Li}$ Shangpu et al. [17]; Gong Qiang et al. [18]); Secondly, if a local government invests massively with borrowed funded, it usually needs to pay a huge amount of interest. Shirakawa found that when the interest burden exceeds the actual return from invested projects, the economy will not be boosted; instead, debt risks may be surfaced [19]; Furthermore, in order to prevent systemic financial risks, local governments may pay off high-cost, short-maturity implicit debts with the funds raised from the bond market. Fourthly, as the relationship between government and the market has not yet been fully rationalized in China, local governments may also invest borrowed funds in competitive fields. However, given the nature of local governments and their platform companies, the investment may be managed in a very extensive way, leading to the lack of competitive advantages. Accordingly, we put forward Hypothesis 2.

$\boldsymbol{H}_{2}$ : all other factors remaining unchanged, when local government's bond financing exceeds a certain level, economic growth will slow down.

$\boldsymbol{H}_{3}$ : for economically developed regions, local government's bond financing is not the decisive factor for economic growth, and bond financing does not have a significantly positive effect on economic growth; for underdeveloped regions, local government's bond financing has begun to show negative effect on economic growth. 


\section{Materials and Methods}

\subsection{Model selection}

For the purpose of this study, we selected the panel smooth transition regression model (PSTR) developed by González, Teräsvirta and Van Dijk [20-21]. The model can not only effectively characterize heterogeneity changes of model parameters across provinces, but also more intuitively profile non-linear changes of parameters with the increase of transition variables, thus allowing us to probe the relationship between the local government's bond financing scale and economic growth.

Therefore, in order to characterize the heterogeneity of parameters between cross-sectional units and the effects of instability over time, we constructed the following twozone non-linear PSTR model:

$$
\begin{aligned}
& \operatorname{GDPr}_{i, t}=\beta_{0}+\beta_{1} X_{i, t}+\beta_{2} X_{i, t} g\left(q_{i, t}, \gamma, c_{j}\right)+\beta^{\prime} \text { Control }+\varepsilon_{i, t} \\
& X_{i, t}=\operatorname{Debt}_{i, t} \\
& \beta=\left(\beta_{3}, \beta_{4}, \beta_{5}, \beta_{6}, \beta_{7}, \beta_{8}\right) \\
& \text { Control }=\left(\text { SFS }_{i, t} \text {,nvestr }_{i, t} \text { Trade }_{i, t}, \text { GovI }_{i, t}, \text { HumR }_{i, t}, \text { Urban }_{i, t}\right)^{\prime}
\end{aligned}
$$

Where, $i=1,2,3, \ldots ; N$ is cross-sectional unit; $t=1,2,3, \ldots$; and $\mathrm{T}$ is the unit of time. The explained variable $G D P r_{i, t}$ is the real GDP growth rate of each province in Period t, and $X_{i, t}$ is the main explanatory variable. Local government's outstanding debts/GDP was used to measure the debt level of each provincial government, i.e. local government debt ratio $\operatorname{Debt}_{i, t}$. $\beta_{0}$ is a constant term; $\quad \beta_{1}$ is a parameter vector for the linear part of the explanatory variable; $\beta_{2}$ is a parameter variable for the non-linear part of the explanatory variable; $\varepsilon_{i, t}$ is a random error term; $q_{i, t}$ is the transition variable; $\gamma$ represents the transition rate, which determines the smoothness of the transition; $c_{j}$ represents the position parameter for smooth transition, i.e. the threshold of transition. In addition, in Equation (13), in order to reduce the endogeneity of the model arising from missing variables, we introduced control variables that impact economic growth: social financing scale $S F S_{i, t}$, level of fixed asset investment Investr $_{i, t}$, level of imports and exports Trade $_{i, t}$, level of government income $G o v I_{i, t}$, human capital $H u m R_{i, t}$ and level of urbanization $\operatorname{Urban}_{i, t}$.

$$
g\left(q_{i, t}, \gamma, c_{j}\right) \text { is a function of the transition variable. }
$$
According to the definitions provided by Granger and Teräsvirta, Teräsvirta and Jansen, and Teräsvirta [22-24], it can be expressed as:

$$
g\left(q_{i, t}, \gamma, c_{j}\right)=\left\{1+\exp \left[-\gamma \prod_{j=1}^{m}\left(q_{i, t}-c_{j}\right)\right]\right\}^{-1}, \quad \gamma>0, \quad c_{1} \leq c_{2} \leq \cdots \leq c_{m}
$$

\subsection{Data sources}

For the purpose of this study, we used quarterly panel data covering 30 provinces in China from 2008 to 2018. The main indicators and data sources are as follows:

\subsubsection{Level of local government's bond financing (Debt).}

Prior to the promulgation of the Budget Law of the People's Republic of China(2014 amendment) in 2014, local governments could only issue urban investment bonds (UI bonds) through platform companies to raise funds. Since 2015, local governments can issue both LG bonds and urban investment bonds through platform companies. Therefore, the data we collected for explanatory variable Debt come from two periods. For Period 1 (2008 to 2014), we collected data on UI bonds issued by platform companies. For Period 2 (2015 to 2018), we collected data on both UI bonds and local government bonds and added them up. Since the National Audit Office of China has defined "local government debt ratio" as the ratio of outstanding debts for which the government is obliged to pay off to current year's GDP, we defined explanatory variable $D e b t$ as a ratio in a bid to eliminate the variations resulting from regional disparity. To alleviate endogeneity, we used the variable lagged by two periods to make estimations.

\subsection{Data sources for different variables.}

Quarterly data on UI bonds and LG bonds were collected from Wind database. Data on GDP growth rate, total imports and exports, number of college students, government income, urban population, and total population were collected from CEInet Statistics Database. Data on social financing scale were collated from the numbers published on the website of the People's Bank of China, and the fixed asset investment index was collected from EPS China Data.

\subsection{Variable Definition}

Table 1 summarizes the descriptions and definitions of the above variables. The data collected do not cover Hong Kong, Macao and Taiwan as they follow different systems, or Tibet as too many numbers are missing.

Table 2 presents descriptive statistics by variable. As can be seen from the table, China's economic growth rate in the past ten years has maintained a relatively high level, approaching $10 \%$. The mean level of local government's bond financing is $37.32 \%$, with the max level reaching $332 \%$ and standard deviation being close to $50 \%$, indicating high variations, which suggests that local governments were facing heavy debt burden during this period and debt 
burden varied greatly across the country.

Table1. Descriptions and definitions of the variables.

\begin{tabular}{llll}
\hline Variable type & Variable & Description & Definition \\
\hline Explained variable & GDPr & Economic growth & GDP growth rate \\
Explanatory & Debt & Level of local government's bond financing & UI bonds / GDP (2008-2014) \\
variable & Trade & Import and export level & Total actual imports and exports/GDP \\
& GovI & Level of government income & General government income/GDP \\
& InvestR & Level of fixed asset investment & Growth rate of fixed asset investment \\
Control variable & SFS & social financing scale & Social financing scale/GDP \\
& Urban & Level of urbanization & Urban population/total population \\
& HumR & Human capital & Logarithm of the number of college students \\
\hline
\end{tabular}

Table2. Descriptive statistics of the variables.

\begin{tabular}{llllll}
\hline Variable & Number of observations & Mean & Standard deviation & Min. value & Max. value \\
\hline GDPr & 1,320 & 0.0980 & 0.0325 & -0.0810 & 0.2510 \\
Debt & 1,320 & 0.3732 & 0.4948 & 0.0000 & 3.3254 \\
Trade & 1,320 & 0.2949 & 0.3475 & 0.0138 & 2.0626 \\
GovI & 1,320 & 0.1117 & 0.0414 & 0.0362 & 0.3405 \\
InvestR & 1,320 & 0.0250 & 0.0396 & -0.0736 & 0.1740 \\
SFS & 1,320 & 0.1099 & 0.1640 & -0.1286 & 1.0872 \\
Urban & 1,320 & 0.5529 & 0.1310 & 0.2912 & 0.8960 \\
HumR & 1,320 & 4.1606 & 0.8118 & 1.4393 & 5.3664 \\
\hline
\end{tabular}

\section{Empirical Results}

\subsection{Test of non-linearity}

Drawing on the approach of González et al. [25], we tested the homogeneity and residual non-linearity by means of LM test, to determine the goodness of fit of the model and the number of position parameters. For the LM test, Chisquare statistics and F-statistics were used respectively, and robustness test was conducted. In order to avoid the effect of sample size on statistics, we followed the Bootstrap approach to carry out Wild Bootstrap (WB) and Wild Cluster Bootstrap (WCB) tests.

As shown in Table 3, the P-value of most statistics in the test of linearity is 0 , which indicates that the model with local government's bond financing scale as the transition variable can reject the linearity hypothesis, and suggests that local government's bond financing scale has a significant nonlinear effect on GDP growth. This model is applicable to PSTR model and can be used for parameter and model estimations.

Table3. Test of linearity based on the transition variable Debt (Homogeneity Test).

\begin{tabular}{|c|c|c|c|c|c|c|c|c|c|c|}
\hline \multirow{2}{*}{ m } & \multicolumn{2}{|c|}{ LM_x } & \multicolumn{2}{|c|}{ LM_F } & \multicolumn{2}{|c|}{ HAC_x } & \multicolumn{2}{|c|}{ HAC_F } & \multirow{2}{*}{$\begin{array}{l}\text { WB } \\
\text { PV }\end{array}$} & \multirow{2}{*}{$\frac{\text { WCB }}{\text { PV }}$} \\
\hline & Test & PV & Test & PV & Test & PV & Test & PV & & \\
\hline 1 & 60.74 & 0.0000 & 58.99 & 0.0000 & 5.443 & 0.0196 & 5.287 & 0.0217 & 0.000 & 0.250 \\
\hline 2 & 68.43 & 0.0000 & 33.20 & 0.0000 & 6.840 & 0.0328 & 3.319 & 0.0365 & 0.000 & 0.000 \\
\hline 3 & 69.66 & 0.0000 & 22.52 & 0.0000 & 6.840 & 0.0772 & 2.211 & 0.0851 & 0.000 & 0.000 \\
\hline
\end{tabular}

When selecting the number of position parameters, we drew on the approach proposed by Luukkonen, Saikkonen and Tersvirta [26]. That is, we used transition function $g\left(q_{i, t}, \gamma, c_{j}\right)$ to make approximation at the first-order Taylor of $\gamma=0$, and thereby obtained the auxiliary regression equation:

$G D \mathrm{r}_{i, t}=\beta_{0}+k_{0}^{\prime} X_{i, t}+k_{1}^{\prime} X_{i, t} q_{i, t}^{m}+\cdots+k_{m}^{\prime} X_{i, t} q_{i, t}^{m}+\beta_{i} \sum_{i=1}^{5}$ Control $_{i, t}+\varepsilon_{i, t}^{*}$

Where, $k_{0}^{\prime}, k_{1}^{\prime}, \ldots, k_{m}^{\prime}$ are parameters to be estimated; $\varepsilon_{i, t}^{*}=\varepsilon_{i, t}+R_{m} k_{i}^{\prime} X_{i, t}, R_{m}$ is the remainder of the Taylor expansion.

Following the approach put forward by González et al. [21], we conducted a hypothesis test for $m$ value in the auxiliary regression model. Their approach is to set the $\mathrm{m}$ value to 3,2 and 1 and then test the original hypothesis for each set value. When $\mathrm{m}=3$, the original hypothesis:

$$
H_{0}^{*}: k_{3}^{\prime}=k_{2}^{\prime}=k_{1}^{\prime}=0 \text {; }
$$

if the hypothesis is accepted, there are three or more position parameters in the model. If the hypothesis is rejected, it means that there are at most two position parameters in the model. In such case, the next step is to test hypotheses 


$$
\begin{aligned}
& H_{01}^{*}: k_{1}^{\prime}=0 \mid k_{3}^{\prime}=k_{2}^{\prime}=0, \\
& H_{02}^{*}: k_{2}^{\prime}=0 \mid k_{3}^{\prime}=0, \\
& H_{03}^{*}: k_{3}^{\prime}=0
\end{aligned}
$$

if the LM test rejects $H_{02}^{*}$ most, then make $\mathrm{m}=2$,

otherwise 1 is taken. According to the results presented in Table 4, the level of rejection is the highest when there is only one transition point, so the optimal number of position parameters $\mathrm{m}$ in the transition function is 1 . We therefore constructed the following function:

GDPr $_{i, t}=\beta_{l}$ Trade $_{i, t}+\beta_{2}$ GovI $_{i, t}+\beta_{3}$ Invest $_{i, t}+\beta_{4}$ SFS $_{i, t}+\beta_{5}$ Urban $_{i, t}+\beta_{6}$ HumR $_{i, t}$

\begin{tabular}{|c|c|c|c|c|c|c|c|c|c|c|}
\hline \multirow{2}{*}{ m } & \multicolumn{2}{|c|}{ LM_x } & \multicolumn{2}{|c|}{ LM_F } & \multicolumn{2}{|c|}{ HAC_x } & \multicolumn{2}{|c|}{ HAC F } & \multirow{2}{*}{$\begin{array}{l}\text { WB } \\
\text { PV }\end{array}$} & \multirow{2}{*}{$\begin{array}{c}\text { WCB } \\
\text { PV }\end{array}$} \\
\hline & Test & PV & Test & PV & Test & PV & Test & PV & & \\
\hline 1 & 60.74 & 0.0000 & 58.99 & 0.0000 & 5.443 & 0.0196 & 5.287 & 0.0217 & 0.000 & 0.250 \\
\hline 2 & 8.06 & 0.0001 & 7.82 & 0.0001 & 1.610 & 0.2045 & 1.562 & 0.2116 & 0.000 & 0.500 \\
\hline 3 & 1.30 & 0.2546 & 1.258 & 0.2622 & 0.460 & 0.4976 & 0.446 & 0.5043 & 0.000 & 0.750 \\
\hline
\end{tabular}

$$
+\beta_{7} \operatorname{Debt}_{i, t}+\beta \operatorname{Debt}_{i, t} g\left(q_{i, t}, \gamma, c_{j}\right)
$$

Table4. Test of residual non-linearity for the number of position parameters $\mathrm{m}$.

\subsection{Estimation of non-linear model parameters}

After correctly setting the PSTR model by means of "test of linearity" and "test of residual non-linearity", we carried out estimation of model parameters. Following the approach put forward by González et al. [26], we estimated the parameters for panel smooth transition regression of local government's bond financing scale and economic growth rate. The graph of the transition function for the PSTR model was hence obtained, as is shown in Figure 3. Table 5 presents the estimates of model parameters and the results of fixed effects model for comparison.

\begin{tabular}{|c|c|c|c|c|}
\hline \multirow{2}{*}{ Variable } & \multicolumn{2}{|c|}{ PSTR model } & \multicolumn{2}{|c|}{ Fixed effects panel model } \\
\hline & Estimates & Standard deviation & Estimates & Standard deviation \\
\hline $\operatorname{Debt}_{i, t} g\left(q_{i, t}, \gamma, c_{j}\right)$ & -0.1242 & 0.3387 & & \\
\hline Parameter position $c_{j}$ & $0.0973 * * *$ & 0.0234 & & \\
\hline Smooth parameter $\gamma$ & 71.0086 & 534.4400 & & \\
\hline Number of transition functions & 1 & & & \\
\hline Trade & 0.0021 & 0.0110 & 0.0037 & 0.0064 \\
\hline GovI & 0.0023 & 0.0324 & -0.0106 & 0.0238 \\
\hline InvestR & $0.1842 * * *$ & 0.0299 & $0.1951 * * *$ & 0.0175 \\
\hline$S F S$ & $-0.0296 * * *$ & 0.0129 & $-0.0331 * * *$ & 0.0024 \\
\hline Urban & $-0.3089 * * *$ & 0.1000 & $-0.2993 * * *$ & 0.0361 \\
\hline$H u m R$ & $0.0427^{*}$ & 0.0370 & $0.0502 * * *$ & 0.0106 \\
\hline Debt & 0.1056 & 0.3469 & $-0.0239 * * *$ & 0.0024 \\
\hline Constant & & & $0.0618^{*}$ & 0.0328 \\
\hline $\mathrm{R}^{2}$ & 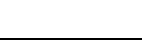 & 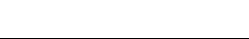 & 0.0752 & 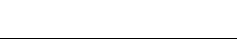 \\
\hline
\end{tabular}

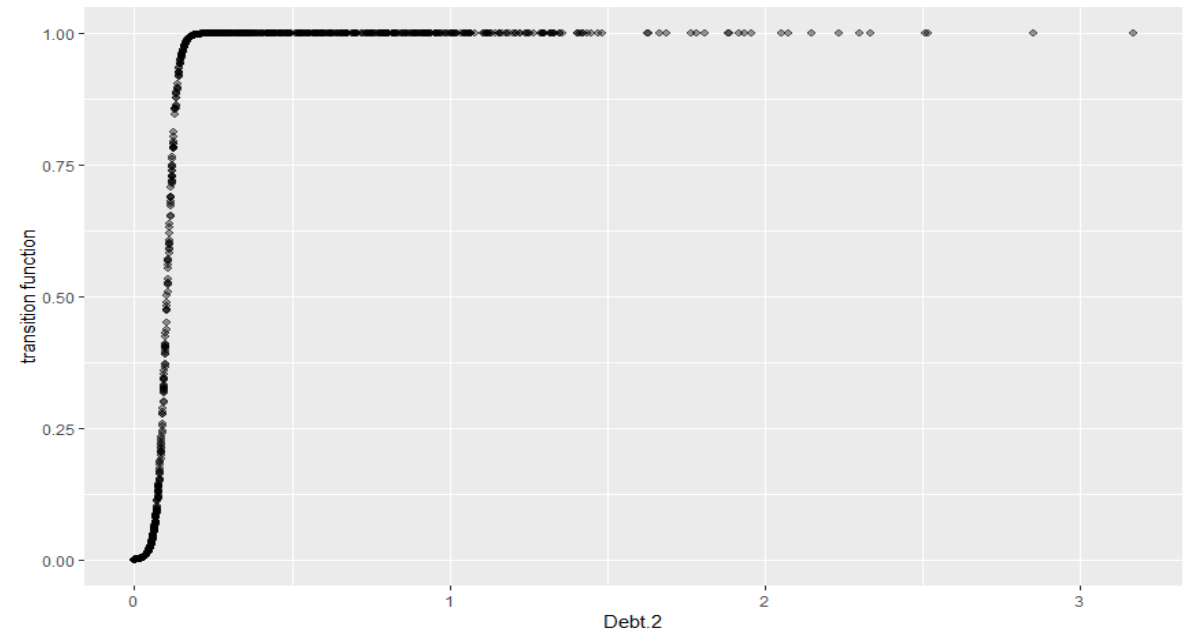

Fig3. Graph of transition function.

Table5. Empirical results from PSTR model and fixed effects panel model. command in R software. 


\subsection{Analysis of effects by province}

For the purpose of this study, we ranked the 30 provinces in terms of per capita GDP at the end of 2018. The top 15 are classified as economically developed regions, while the others economically underdeveloped regions. The rankings and classification are presented in Table 6 . We then carried out PSTR regression for each province, with the results presented in Tables 7 and 8 .

Table6. Real GDP per capita by province, 2018.

\begin{tabular}{ccccc}
\hline \multicolumn{2}{c}{ Economically developed regions } & & \multicolumn{2}{c}{ Economically underdeveloped regions } \\
\cline { 1 - 2 } $\begin{array}{c}\text { Provinces (municipalities and } \\
\text { autonomous regions) }\end{array}$ & $\begin{array}{c}\text { Per capita GDP } \\
\text { (RMB yuan) }\end{array}$ & & $\begin{array}{c}\text { Provinces (municipalities and } \\
\text { autonomous regions) }\end{array}$ & $\begin{array}{c}\text { Per capita GDP } \\
\text { (RMB yuan) }\end{array}$ \\
\hline Beijing & $140,748.21$ & Hunan & $52,800.17$ \\
Shanghai & $134,830.18$ & Hainan & $51,717.29$ \\
Tianjin & $120,605.54$ & & Henan & $50,032.13$ \\
Jiangsu & $115,015.34$ & & Xinjiang & $49,056.12$ \\
Zhejiang & $97,955.64$ & & Sichuan & $48,768.89$ \\
Fujian & $90,850.14$ & Hebei & $47,655.96$ \\
Guangdong & $85,737.50$ & & Qinghai & $47,498.14$ \\
Shandong & $76,110.13$ & & Anhui & $47,452.12$ \\
Inner Mongolia & $68,228.97$ & Jiangxi & $47,303.51$ \\
Hubei & $66,531.27$ & Shanxi & $45,230.16$ \\
Chongqing & $65,649.80$ & $63,239.62$ & Heilongjiang & $43,231.04$ \\
Shaanxi & $58,072.05$ & $55,521.23$ & Guangxi & $41,316.50$ \\
Liaoning & $53,845.75$ & & Guizhou & $41,129.03$ \\
Jilin & & Yunnan & $37,020.97$ \\
Ningxia & & Gansu & $31,267.57$ \\
\hline
\end{tabular}

Table7. Estimation of the effect of local government bond financing on economic growth in economically developed regions

\begin{tabular}{|c|c|c|c|c|}
\hline Region & First extreme regime & Second extreme regime & gamma & c \\
\hline Beijing & -0.0331 & -0.0228 & 21.1954 & 0.3835 \\
\hline Shanghai & 0.0902 & 0.0070 & 34.9745 & 0.2400 \\
\hline Tianjin & 0.2125 & -0.0681 & 29.9523 & 0.2009 \\
\hline Jiangsu & -0.0021 & -0.0308 & 49.5384 & 0.1563 \\
\hline Zhejiang & 0.0442 & -0.0268 & 60.2548 & 0.1268 \\
\hline Fujian & 0.0716 & -0.0369 & 84.4095 & 0.1039 \\
\hline Guangdong & 1.0868 & -0.0389 & 112.6700 & 0.0341 \\
\hline Shandong & -0.1256 & -0.0584 & 206.9700 & 0.0417 \\
\hline Inner Mongolia & -0.4740 & -0.0593 & 112.4080 & 0.1877 \\
\hline Hubei & 1.6650 & -0.0337 & 117.8080 & 0.0316 \\
\hline Chongqing & 0.2240 & -0.0262 & 33.0202 & 0.1935 \\
\hline Shaanxi & 0.1853 & -0.0412 & 79.0280 & 0.0756 \\
\hline Liaoning & -0.2110 & -0.0244 & 109.2450 & 0.0996 \\
\hline Jilin & 4.5163 & -0.0506 & 165.4990 & 0.0169 \\
\hline Ningxia & -0.4642 & -0.0203 & 115.7020 & 0.0493 \\
\hline
\end{tabular}

Table8. Estimation of the effect of local government bond financing on economic growth in economically underdeveloped regions

\begin{tabular}{cccc}
\hline Region & First extreme regime & Second extreme regime & gamma \\
\hline Hunan & 1.4134 & -0.0211 & 78.1856 \\
Hainan & -1.0106 & -0.0580 & 312.2800 \\
Henan & 1.9177 & -0.0378 & 0.0572 \\
Xinjiang & 0.3671 & -0.0190 & 0.0309
\end{tabular}




\begin{tabular}{ccccc} 
Sichuan & 2.6273 & 0.0034 & 74.3424 & 0.0481 \\
Hebei & 4.0472 & -0.0188 & 208.0500 & 0.0170 \\
Qinghai & 0.1314 & -0.0226 & 25.2214 & 0.2807 \\
Anhui & 0.3488 & -0.0378 & 48.7008 & 0.1194 \\
Jiangxi & 0.6450 & -0.0224 & 66.0507 & 0.0623 \\
Shanxi & 12.4790 & -0.0048 & 132.9920 & 0.0188 \\
Heilongjiang & 2.0624 & -0.0260 & 149.5350 & 0.0255 \\
Guangxi & 2.5424 & -0.0230 & 78.0057 & 0.0247 \\
Guizhou & 1.2851 & 0.0012 & 82.0508 & 0.0634 \\
Yunnan & 0.0016 & -0.0061 & 71.1751 & 0.1036 \\
Gansu & 0.2667 & -0.0135 & 31.4577 & 0.2254 \\
\hline
\end{tabular}

In order to further investigate the non-linear transition relationship between local government's bond financing and economic growth, we followed the approach of Huang Yuran et al. to calculating the corresponding relationship parameter values via Equation (6) on the basis of parameter estimates of the PSTR model [27]. We calculated the mean of local government's bond financing scale by province from 2008 to 2018 , and calculated the corresponding GDP growth rate according to the parameter estimates of the PSTR model. On that basis, we drew the three-point relationship between economic growth rate by province (expressed by Y) and local government's bond financing scale (expressed by $\mathrm{X}$ ) (Figure 4).

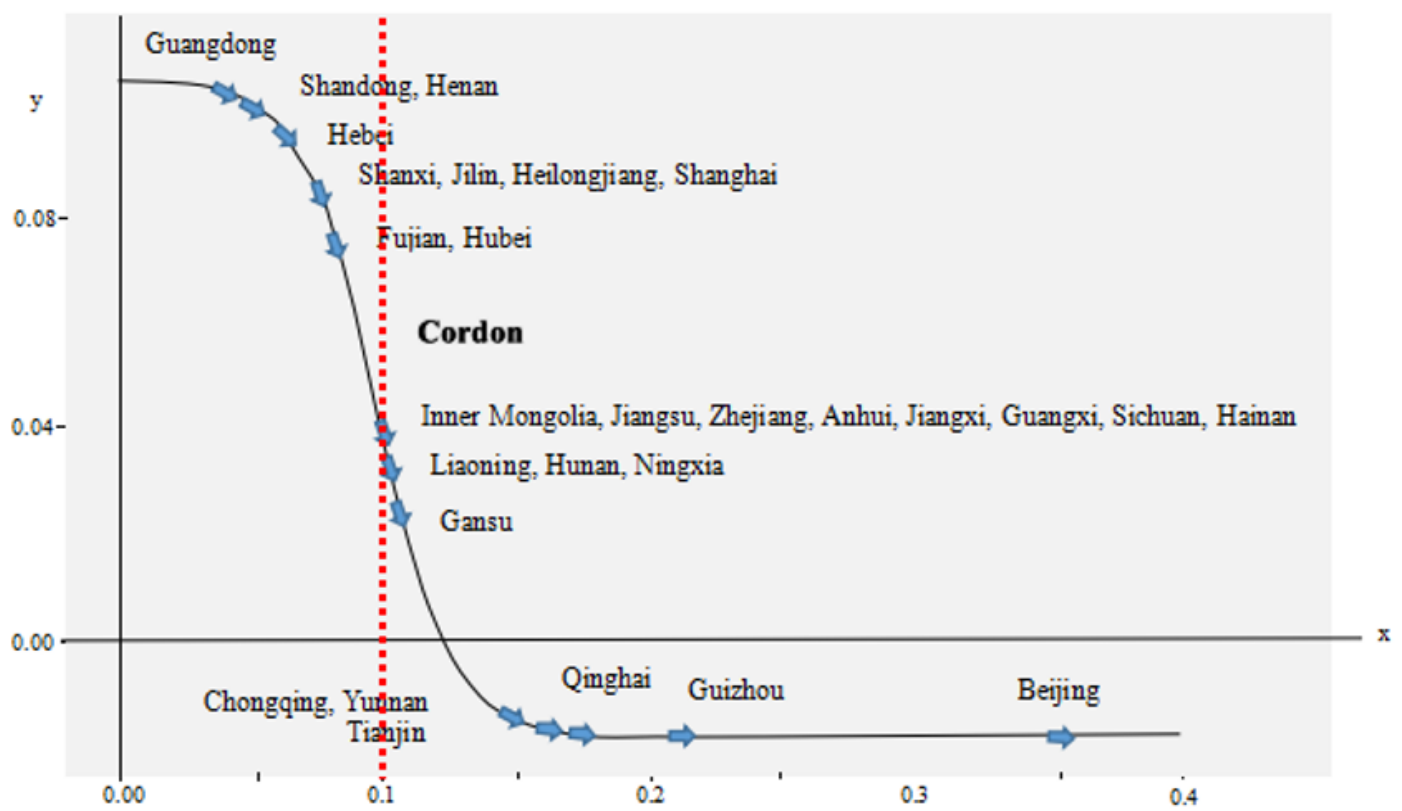

Fig4. Non-linear relationship between local government's bond financing scale and economic growth by province

On the whole, the effects of local government's bond financing on economic growth in most provinces conform to expectations. When the level is lower than the threshold, local government's bond financing has a positive effect on economic growth, while when it is higher than the threshold, local government's bond financing has a negative effect on economic growth to a certain extent. Only a few provinces do not conform to expectations. As can be seen from Figure 4, when the level is higher than the $10 \%$ alarm level, local government's bond financing begins to have a negative effect on local economy. In most
$\beta=\frac{\partial\left(G D P r_{i, t}\right)}{\partial X_{i, t}}=\beta_{I}+\sum_{j=1}^{\gamma} \beta_{j} g_{j}\left(\bar{q}_{i, t}, \gamma_{j}, c_{j}\right) \quad X_{i . t}=\operatorname{Debt}_{i, t}$ (5)

As can be seen from Figure 4, the threshold values of the effect of local government's bond financing on economic growth range between 0.05 and 0.15 . When the threshold variable is close to 0.0973 , that is, when the level of local government's bond financing is less than 0.0973, the effect on economic growth mainly depends on the linear part, and is positive. However, when the level is greater than 0.0973 , local government's bond financing begins to have non-linear negative effect on economic growth gradually. provinces, the level is around $10 \%$.

\section{Discussion}

Firstly, it can be seen that the transition function does not have an "S" shape; instead, it approximately presents an "L" shape. Nevertheless, it still reflects the smooth transition of the effect of local government's bond financing on economic growth. In the graph, each point represents an observation. By combining smooth 
parameters, position parameters and transition function, we found that most of the observations in the sample are located in the high regime, while a few are in the low regime. The transition function gradually completes the smooth transition from 0 to 1 when $c_{j}=0.0973$. In addition, when $\gamma=71.0086$, the curve of the transition part is steep and the transition is fast, which indicates that changes in local government's bond financing scale will have a big impact on economic growth near the location parameters.

That is because as a relatively independent stakeholder, local government is responsible for driving local economic growth. After the tax reform in 1994, central government and local governments divide spending assignments and responsibilities. As local government's responsibilities outweigh their spending assignments, they have a strong motive to make investment with borrowed funds. What's more, for a long time, Chinese government has been appraising the performance of local officials by looking at the local GDP. As a result, local governments are competing with one another by driving economic growth through debt-financed investment. Consequently, local government's bond financing tends to have a nonlinear relationship with economic growth.

Secondly, the regression results in Table 5 confirm hypotheses 1 and 2. Generally speaking, economic growth has a strong dependence on local government's bond financing. Once bond financing exceeds the threshold, negative effects will appear. Specifically: the interaction variable $\operatorname{Debt}_{i, t} g\left(q_{i, t}, \gamma, c_{j}\right)$ between the level of local government's bond financing and the transition function has an impact on economic growth at a $1 \%$ level of significance. This shows that the local government can only effectively drive economic growth to a certain extent after financing in the bond market; when the level of local government's bond financing is lower than the threshold variable (0.0973), the system is in the low transition regime where local government's bond financing has a positive effect on economic growth $(0.1056)$; on the contrary, when the system is in the high transition regime, the elasticity coefficient of local government's bond financing to economic growth is -0.1242 , which shows that after local government's bond financing increased rapidly, which led to aggravated local government debt, the real economy did not achieve corresponding growth.

The model also shows that, on the whole, fixed asset investment can significantly promote economic growth, while the level of urbanization has a significantly negative correlation with economic growth. There is a negative correlation between social financing scale and economic growth, which may be attributed to the fact that bond proceeds have been largely used to pay off local government's implicit debts. The relationship between government income and economic growth is not significant, which is attributed to the fact that Chinese local governments have run deficits for a long time and their tax revenues, which account for the majority of government income, constitute a small proportion of local economies.

Thirdly, on the whole, it can be seen in Table 7 and
Table 8 that the effect of local government's bond financing on economic growth in most provinces conforms to Hypotheses 1 and 2. When the level of local government's bond financing is below the threshold, infrastructure investment will be effectively promoted, hence creating more opportunities for private investment, with economic growth boosted. In such cases, for example, for every increase of 1 percentage point in the level of local government's bond financing in Hebei Province, the economic growth rate will increase by 4.05 percentage points. However, when the level of local government's bond financing is above the threshold, the effect on economic growth will gradually diminish and eventually turn negative due to soft budget constraints, high interest expenses and debt replacement. For every increase of 1 percentage point in the level of local government's bond financing in Hebei Province, the economic growth rate will decline by 0.019 percentage points.

By comparing Table 7 and Table 8, we found that majority of the provinces that do not conform to Hypotheses 1 and 2 are developed regions, such as Beijing, Shanghai, Jiangsu, Liaoning and Shandong. Among others, the effects of local government's bond financing scale on economic growth are also different in the two regimes. For Beijing, Jiangsu, Shandong, Inner Mongolia, Liaoning and Ningxia, the effects are both negative in the two regimes, while for Shanghai, the effects are both positive. This may be attributed to the fact that these economically developed provinces have large economies, betterestablished infrastructure and mature investment markets, and their economic growth rate is therefore less impacted by local government's bond financing. Accordingly, government financing does not play a decisive role in economic development. Hence, local government's bond financing scale has no significant effect on economic growth. However, only a few provinces (Hainan, Sichuan and Guizhou) out of the underdeveloped regions do not conform to expectations. This is attributed to the fact that in economically underdeveloped regions, economic growth is more dependent on governments' investment in infrastructure and more sensitive to local government's bond financing due to the lack of sound regulations on the investment market and the lack of strong investment awareness. Therefore, Hypothesis 3 is confirmed to be valid. What's more, as can be seen from Tables 7 and 8 , the transition speed of each province is relatively high, which suggests that the economic growth rate is particularly sensitive to the changes in the scale of financing. It can also be said that when local government's bond financing scale changes near the threshold value, the parameter value will rapidly move from the first extreme regime to the second extreme regime.

Finally, as can be seen from Figure 4, the level of local government's bonding financing has exceeded 0.15 in Chongqing, Yunnan, Tianjin, Qinghai, Guizhou and Beijing, and even reached 0.35 in Beijing. As Chongqing, Tianjin and Beijing are municipalities directly administered by the central government, and Beijing is China's political, economic and cultural center, they have been undertaking relatively heavy tasks of developing public infrastructure. The level of bond financing is, therefore, relatively high, and the effect on economic 
growth does not fully manifest itself. The level of local government's bonding financing of Chongqing, Yunnan, Qinghai and Guizhou is between 0.15 and 0.21 , and that of Ningxia and Gansu is above 0.1 , which is partly attributed to the lack of economic vitality in underdeveloped regions in China's west and high level of dependence of economic growth on government investment stimulus. Local government's bond financing has begun to have a negative effect on economic growth in these provinces, which suggests an urgent need to address government bond financing.

Provinces below the threshold are largely located in China's central and eastern regions, including Guangdong, Shandong, Shanghai and Fujian, which shows that local government's bond financing in these regions does not have a significantly positive effect on economic growth. The level in Guangdong is below 0.05, which may be attributed to its location advantages and sound economic foundation, as it is an early mover of opening-up. In Guangdong, the key drivers of economic growth are exports and consumption, instead of government investment.

The level of local government's bond financing in Jiangsu, Zhejiang and Sichuan is almost at the threshold of 0.1 , which shows that these provinces can not only fully tap the positive effect of bond financing on economic growth, but also strictly control the scale of bond financing so that it will not have a negative impact on the economy. Therefore, Hypothesis 3 is again proven to be valid.

\section{Conclusions}

This paper examines the effect of local government's bond financing on economic growth in 30 Chinese provinces by using the panel smooth transfer regression model. It shows that with the changes in local government's bond financing, the effect on economic growth presents a progressive nonlinear pattern. That is, as local government's bond financing scale increases, the effect on economic growth will gradually diminish and then turn negative, and the transition from one regime to another will be very fast. In addition, the relationship between local government's bond financing and economic growth is subject to regional disparity. In some economically developed regions with sound market economies, government's financing and investment is not a decisive factor in driving economic growth. From the perspective of non-linear transition, provinces that fall below the threshold are largely located in central and eastern parts of China, which suggests that the role of government's financing and investment in promoting economic growth has not yet been fully unleashed in these regions. For some economically underdeveloped regions, however, the government's bond financing has begun to bring negative effects to economic growth. The main reasons are analyzed as below.

First of all, whether the funds raised from issues of LG bonds can promote economic growth depends on how much of the bond proceeds has been actually invested by local governments. What's more, the LG bond market is one of the debt financing channels for local governments, and the post-issuance effects are closely related to other ways of financing. Social financing scale is an important indicator to characterize the scale of funds raised by local governments via other ways of financing. From Table 5, we can see that the coefficient of the variable SFS (social financing scale of local governments) is negative (0.0296), which indicates that as the peak periods of debt repayment came in recent years, much of the bond proceeds has been used to pay off existing debts with a view to fending off systemic financial risks, instead of being invested in the real economy.

Secondly, as the money supply is limited and governments have better creditworthiness, local government's bond financing has an obvious "crowdingout effect" on the financing of private economic entities. Compared with other types of firms, local governments and their platform companies can issue bonds against their creditworthiness, with higher likelihood of success and at lower cost. However, given the limited money supply, when a large amount of funds is raised by local governments and their platform companies, the funds available to private economic entities will decrease, thus leading to lower level of physical assets formation and production capacity.

Thirdly, although bond financing has positive effect on economic growth on the whole, urbanization has obviously "consumed" the funds, which is attributed to the fact that public investment in the process of urbanization usually does not bring about economic growth in the short term and is prone to incur huge financial expenses. For a long time, Chinese local governments have relied excessively on the transfer of land use rights to generate government income and on real estate industry to drive economic growth. At present, however, as land resources available for transfer and development potential of real estate industry have been shrinking, immediate economic benefits that can be generated after bond financing have also begun to drop significantly. The existence of the threshold effect of local government's bond financing in economically developed regions is attributed to the rapid increase of land development cost and urbanization cost, and fluctuations in human resources. In underdeveloped regions, however, there is a negative correlation between these two, which is attributed to public infrastructure projects with low short-term returns and long payback periods invested by local governments to compete with one another in terms of urbanization.

\section{Acknowledgments}

This paper is funded by the Chinese National Funding of Social Science (the western program). Grant No. 16XGL005. The National Social Science Foundation is the main channel for China to support basic research in the field of scientific research. It is oriented to the whole country and focuses on supporting researchers in Institutions of higher learning and scientific research institutions with good research conditions and research strength. 


\section{References}

1. Tiebout, C. M. (1956) A Pure Theory of Local Expenditures. Journal of Political Economy, 64: 416-424.

2. Hildreth, W. B.; Miller, G. J. (2002) Debt and the Local Economy: Problems in Benchmarking Local Government Debt Affordability. Public Budgeting \& Finance, 22: 99-113.

3. Panizza, U.; Presbitero, A. F. (2014) Public Debt and Economic Growth: Is There A Causal Effect? Journal of Macroeconomics, 41: 21-41, doi: 10.1016/j.jmacro.2014.03.009.

4. Stella, S.; George, V. (2015) The Impact of Government Debt on Economic Growth: An Empirical Investigation of the Greek Market. The Journal of Economic Asymmetries, 12:34-40, doi: 10.1016/j.jeca.2014.10.001.

5. Dotsey, M. (1994) Some Unpleasant Supply Side Arithmetic. Journal of Monetary Economics, 33: 507-524.

6. Baldacci, E.; Kumar, M. S. (2010) Fiscal Deficits, Public Debt, and Sovereign Bond Yields. IMF Working Paper. pp. 1-29.

7. Cochrane, J. H. (2011) Understanding Policy in the Great Recession: Some Unpleasant Fiscal Arithmetic. European Economic Review, 55:2-30.

8. Reinhart, C. M.; Rogoff, K. S. (2010) Growth in a Time of Debt. American Economic Review, 100:573- 578 .

9. Checherita, W. C.; Rother, P. (2012) The Impact of High Government Debt on Economic Growth and Its Channels: An Empirical Investigation for Euro Area. European Economic Review, 56:1392-1405.

10. Mitze, T.; Matz, F. (2015) Public Debt and Growth in German Federal State: What Can Europe Learn? Journal of Policy Modeling, 37:208-228.

11. Diao, W. T. (2016) A Research on the Moderate Scale of China's Local Government Debt in the Perspective of Economic Growth: Using the Provincial Data. On Economic Problems. pp. 5054, doi:10.16011/ j.cnki.jjwt. 2016.03.010.

12. Xiang, H. J.; Wu, J.; Xie, J. (2017) Does Local Debt Affect Economic Fluctuation. China Industrial Economics, 1: 43-61, doi: 10.19581/j.cnki.ciejournal.2017.01.003.

13. Fan, J. Y.; Mo, J. W. (2014) Local Government Debt, Land Market Institution and Reginal Industrial Growth. Economic Research Journal, 49: 41-55.

14. Xue, C. S.; Cheng, L.; Zhuang, J. Q. (2016) Influence and mechanism of local debts on regional economic growth - Analysis on panel quantile model. Economist, 5:77-86, doi: 10.16158 /j.cnki.51-1312 /f.2016.05.010.

15. Zhu, W. W.; Chen, Y. (2014) Chinese Local Government Debt and Regional Economic Growth. Finance and Trade Research, 25: 114-121, doi: 0.19337/j.cnki.34-1093/f.2014.04.014.

16. Mao, J.; Huang, C. Y.(2018)Local Debts, Regional Disparity and Economic Growth: An Empirical Study Based on China's Prefecture-Level Data. Journal of Financial Research, 455: 1-19.

17. Li, S. P.; Zheng, Z. H.; Luo, B. L.(2015) Resource Basis, Soft Budget Constrains and Local Government Debts. Contemporary Finance \& Economics, 10:28-38,doi: 10.13676/j.cnki.cn361030/f.2015.10.003.

18. Gong, Q.; Wang, J.; Jia, K. (2011) A Survey of Research on Local Government Debts and Fiscal Decentralization. Economic Research Journal, 46: 144-156.

19. Shirakawa, M. (2012) Sustainability of Government Debt: Preconditions for Stability in the Financial System and Prices. Financial Stability Review, 16: 169-181.

20. González, A.; Teräsvirta, T.; Dijk, D. V. (2004) Panel Smooth Transition Regression Model and an Application to Investment under Credit Constraints. Working Paper, Stockholm School of Economics.

21. González A, Teräsvirta T, Dijk D V. (2005) Panel Smooth Transition Regression Models. SSE/ EFI Working Paper Series in Economics and Finance.

22. Granger, C. W. J.; Teräsvirta, T. (1993) Modelling Nonlinear Economic Relationships. Oxford University Econometric, 25: 56-89.

23. Teräsvirta, T. (1994) Specification, Estimation, and Evaluation of Smooth Transition Autoregressive Models. Journal of the American Stetistical Association, 89: 208-218.

24. Jasen, E. S.; Teräsvirta, T. (1996) Testing Parameter Consrancy and Super Exogeneity in Econometric Equations. Oxford Bulletin of Economics and Statistics, 58: 735-763.

25. González, A.; Teräsvirta, T.; Dijk, D. V.; Yang, Y. K. (2017) Panel Smooth Transition Regression Models. Working paper.

26. Luukkonen, R.; Saikkonen, P.; Tersvirta, T. (1988) Testing Linearity against Smooth Transition Autoregressive Models. Biometrika. pp. 491-499.

27. Huang, Y. R.; Lu, Z. Q.; Li, Z. B.(2018) The Relationship among Local Government Debt, Regional Financial Difference and Economic Growth - Based on Nonlinear PSTR Model. Modern Economic Science, 40: 1-12+124. 